Резюме

Потурай К.С. Особенности договорной формы охраны субъективных прав интеллектуальной собственности на кинематографическое произведение в соответствии с законодательством Украины и стран Европейского Союза.

В статье раскрываются особенности договорной формы субъективных прав интеллектуальной собственности на кинематографическое произведение в соответствии с законодательством Украины и стран Европейского Союза как основной формы охраны произведений кинематографии. Анализируются вопросы авторского договора в разрезе законодательства Украины и Франции.

Ключевые слова: автор, охрана, произведение кинематографии, отчуждение права, авторский договор.

\title{
Summary
}

Kateryna Poturai. The features of the contractual form of protection of subjective intellectual property rights for a cinematographic work under the laws of Ukraine and the countries of the European Union.

The article reveals the features of the contractual form of subjective intellectual property rights to a cinematographic work under the laws of Ukraine and the European Union as the main form of protection of cinematographic works.

The author emphasizes that in modern development of copyright relations, civil law has abandoned the legislative consolidation of the concept of copyright agreement, yet only lists and discloses the sense of its types.

Thus, at the legislative and theoretical level, the problem of classifying a copyright agreement on the creation of a cinematographic work as an agreement on the alienation of exclusive rights or a license agreement still remains unresolved. At the present stage, the legal regulation of the creation and use of films is further complicated by the fact that many film studios instead of copyright agreements enter into refit contracts on the creation of films.

The author draws attention to the fact that the French legal doctrine does not see any difference between the subject of the contract and the content of the obligation and uses such concepts as synonyms. The French legislator does not give a general concept, which would reveal the main features of the copyright agreement. However, the provisions of the French Intellectual Property Code directly indicate the possibility of assignment of the author's property rights (succession in a certain part of copyright) on the basis of the contract. In the French literature and in the practice of courts it is unanimously recognized that from the point of view of general civil law the assignment of exclusive property copyrights is in principle a civil contract of sale of property, in turn a license is a civil contract of property lease.

The author also emphasizes that there is a necessity to regulate the conclusion of copyright agreements with all subjects of a cinematographic work, which may have intellectual property rights in connection with the creation of such a work.

Key words: author, protection, cinematography, alienation of rights, copyright agreement.

DOI: $10.36695 / 2219-5521.4 .2020 .58$

УДК 347.465

\section{Є.А. ТИМОШЕНКО}

Єлизавета Анатолї̈на Тимошенко, асистент кафедри Вінницького національного аграрного універсumemy*

ORCID: 0000-0001-6852-6242

\section{ШТУЧНИЙ ІНТЕЛЕКТ ЯК СУБ’ЄКТ ПРАВА ІНТЕЛЕКТУАЛЬНОЇ ВЛАСНОСТІ}

Постановка проблеми. На сьогодні активний розвиток інформаційного суспільства породжує закономірні зміни в правовідносинах, а саме в їх суб'єктному складі. Сучасна система нормативного-правового та державного регулювання відносин інтелектуальної власності потребує коригування згідно вимогам часу. Розгляд цієї проблеми дасть змогу розкрити специфіку штучного інтелекту, а також ретельно дослідити його структуру. Можна констатувати, що наразі питання права власності штучного інтелекту на об'єкти інтелектуальної власності в умовах розвитку інформаційного суспільства $€$ недостатньо розробленим і розглядається переважно в окремих наукових статтях.

Аналіз останніх досліджень і публікацій. Теоретичною основою дослідження $є$ наукові роботи таких учених, як Б.Д. Алгроув, М. Гілті, Р.А. Мерзлікіна, З.В. Пічкурова, Є.О. Харитонов, О.І. Харитонова, Е.А. Файгенбаум.

Формулювання мети статті. Дослідити поняття штучного інтелекту (далі - Ш). Проаналізувати види штучного інтелекту та їх взаємозв'язок з правом власності. Запропонувати можливі варіанти правового статусу та визначення правової природи ШІ в контексті права інтелектуальної власності.

Виклад основного матеріалу. Вперше термін «інтелектуальна власність» був запроваджений у Конвенції про заснування Всесвітньої організації інтелектуальної власності (далі - ВОІВ), прийнятій у Сток-

(c) Є.А. Тимошенко, 2020

* Yelizaveta Tymoshenko, Assistant of department of "Vinnitsa National Agrarian University" 
гольмі 14 липня 1967 p., і з того часу він почав застосовуватися в міжнародних договорах і в законодавстві багатьох країн світу. ВОІВ вказує, що інтелектуальна власність - це закріплені законом права, які є результатом інтелектуальної діяльності в промисловій, науковій, літературній та художніх галузях ${ }^{1}$.

Інтелектуальна власність охороняється законом за допомогою, наприклад, патенту, авторського права чи права на товарний знак, що дозволяє авторам отримувати визнання у певній сфері та фінансову винагороду за свою працю. Це прямо закріплено у ст. 27 Загальної декларації прав людини, яка передбачає захист моральних і матеріальних інтересів, що є результатом наукових, літературних або художніх праць автора.

3.В. Пічкурова зазначає, що «...інтелектуальна власність являє собою сукупність відносин щодо володіння, користування та розпорядження результатами інтелектуальної діяльності людини в галузі науки, технологій, літературно-мистецької діяльності... з економічного погляду інтелектуальну власність можна тлумачити як сукупність результатів інтелектуальної діяльності людини, які здатні приносити економічну вигоду, і щодо використання яких виникають відносини володіння та розпорядження»².

Наскільки розвивається інформаційне суспільство настільки і розвивається законодавство. Як і раніше, попит на права інтелектуальної власності зростає швидше, ніж світова економіка. І з розвитком інформаційного суспільства звична для нас система інтелектуальної власності абсолютно точно не втрачає своєї актуальності. Навпаки, вона використовується активніше, ніж будь-коли. Однак постають нові виклики, результатом яких може стати не заміна усієї системи інтелектуальної власності, а створення в ній додаткового розділу, який вже давно потребує законодавчого регулювання. Йдеться про штучний інтелект. До прикладу, ШІ вже вміє генерувати музичні твори. Ще у 2017 р. світ познайомився з Ампер. Це штучний інтелект, який використовує алгоритми машинного навчання, щоб самостійно складати та виконувати пісні. Ампер був створений командою професійних музикантів та експертів 3 технологій як платформа для створення професійної музики музикантами-аматорами. Таким чином, Ампер став першим штучним інтелектом, який сам випустив свій перший музичний альбом.

Вже існують юридичні компанії, які розробляють, наприклад, програми для прогнозування результату судової справи. Цей напрям користується попитом та допомагає адвокату у його роботі, як стверджують самі розробники. У Пекіні судді-роботи беруть активну участь у судовому процесі. У Китаї офіційно в онлайнцентрі інтернет-суду відбувається розгляд справи за участі штучного інтелекту.

Вперше патент на винахід штучним інтелектом був зареєстрований у 1980 р., але тоді це було скоріше заради експерименту та щоб заявити міжнародній спільноті, що настає новий етап розвитку інформаційного суспільства. Його основною характеристикою є визнання інформації одним 3 найважливіших суспільних ресурсів, а інформаційний сектор економіки (виробництво, зберігання, обробка, передача і споживання інформації) - одним із найважливіших видів суспільної діяльності, який створює інформаційно-комунікаційну базу для формування глобального інформаційного суспільства та розвитку науково-технічного, соціально-економічного й освітньо-культурного прогресу. Це поняття покликане відобразити об' єктивну тенденцію нового етапу еволюції цивілізації, пов'язаного з появою нових інформаційних і телекомунікаційних технологій, нових потреб і нового способу життя.

На сьогодні продовжують надходити заявки на отримання патенту на винаходи, створені автономно штучним інтелектом, якого вказують винахідником, а власника штучного інтелекту - заявником на патент i кінцевим бенефіціаром будь-яких виданих патентів. Але проблема полягає в тому, що в законодавстві різних країн, і України в тому числі, винахідником визначена особа, яка безпосередньо дослідила та зробила внесок у створення об'єкта інтелектуальної власності. Також більшість юрисдикцій напряму вимагає, щоб у патентних заявках винахідником була вказана фізична особа. Ця вимога створена для захисту і визнання прав винахідників-людей. На практиці більшість патентів належить підприємствам, як роботодавцям винахідників. Таким чином, навіть якщо фізична особа отримує патент на своє ім'я, то потім він переходить за договором або за законом до компанії. Це може бути і автоматичний перехід до роботодавця, якщо винахід створений в рамках трудових обов'язків працівника. У будь-якому випадку, навіть коли винахідник не володіє патентом, законодавство захищає його, вимагаючи вказувати фізичну особу в якості винахідника.

У зв’язку з цим науковці поділяють суб'єктів права інтелектуальної власності на початкових і похідних.

Початковими суб'єктами прав на результати інтелектуальної діяльності є автори, артисти-виконавці, винахідники, селекціонери, дизайнери, програмісти та ін. Загалом це завжди тільки фізичні особи, творчою працею яких створено результат інтелектуальної діяльності. Вони в першу чергу набувають особисті немайнові та майнові права на свої твори.

Похідними суб'єктами можуть бути фізичні та юридичні особи, які на підставі закону, договору чи іншого правочину набули майнові права інтелектуальної власності на результат інтелектуальної, творчої діяльності. Таким чином, їхні права походять від первинних суб'єктів. Їх головна відмінність полягає у тому, що обсяг прав перших значно ширший за останній.

ШІ активно використовується в адміністративному управлінні інтелектуальної власності, завдяки здатності обробити велику кількість інформації за короткий час. Всесвітня організація інтелектуальної власності розробила інструмент пошуку зображень на основі ШІ - він шукає зображення товарного знаку та промислового зразка серед тисяч в базі даних. Такий спосіб опрацювання інформації значно скорочує час на обробку даних.

Насамперед потрібно розуміти, що далеко не будь-який штучний інтелект може претендувати на право інтелектуальної власності. Лише машина, яка здатна до мислення, аналізу та прогнозування ситуації може прирівнюватись до фізичної особи. 
Можна виділити чотири типи штучного інтелекту.

1. «Реактивні машини» - це перший етап будь якого ШІ. Він не має змоги навчатись, $є$ найпростішим $\mathrm{i}$ в нього закладена лише одна задача - це відповідати на чітко прописаний в комп'ютерному коді запит.

2. Наступний тип називають «обмежений пам'яттю». Тобто він запам'ятовує останні дії, аналізує їх і має змогу видати кращий результат за запитом. Але найчастіше, так як об'єм пам'яті обмежений, запам'ятовується лише останній результат, а також цей тип штучного інтелекту не має змогу зібрати кілька результатів разом, проаналізувати їх і спрогнозувати якусь дію.

3. «Теоретично розумний» - коли штучний інтелект здатний взаємодіяти 3 мисленням і поведінкою людини. Яскравим прикладом є безпілотний автомобіль, який аналізує ситуацію на дорозі, зчитує манеру їзд машин, що їдуть поруч, і підлаштовується під них. Але це лише початок розвитку цього типу інтелекту, оскільки машина поки не розпізнає емоції, тон голосу та настрій людини. Вона просто виконує набір команд, хоч і може спрогнозувати кращий варіант ${ }^{3}$.

4. Останнім типом ШІ $є$ «усвідомлюючий себе». Він поки знаходиться на стадії розробки. Самосвідомий інтелект, звісно, значно перевищить людський, буде незалежним і, ймовірно, людям доведеться домовлятися про умови співіснування з суттю, яку він створив ${ }^{4}$. Більшість експертів пов'язують прогрес у розвитку ШІ з розвитком нейронних мереж - це один з напрямів досліджень в області штучного інтелекту, засноване на моделюванні біологічних процесів, які відбуваються в людському мозку. Саме їм ми зобов'язані появі вражаючих результатів у розпізнаванні мови і зображень, постановці медичних діагнозів, перекладі тексту і створення зображень, генерації мови та музичної композиції. Наразі фахівці визнають нейронні мережі одним із кращих алгоритмів машинного навчання, а рішення та дії на їх основі показують на даний момент найвидатніші результати. Тож варто зазначити, що «самосвідомий» тип ШІ буде заснований саме на цьому алгоритмі, який в принципі копіює структуру головного мозку людини.

Традиційно право авторства на створене роботом твір не ставилося під сумнів, оскільки робот функціонує за певним алгоритмом, який пише для нього людина. Отже, і авторство на такий твір визнається за людиною. Більшість юрисдикцій визначають твір охороноздатним, якщо він відповідає певним критеріям, серед яких присутні оригінальність і творча складова. При цьому більшість країн, включаючи Італію та Німеччину, не визнають ймовірність наявності хоча б чогось творчого у штучного інтелекту.

Резолюція ЄП «Норми цивільного права про робототехніку» пропонує закріпити правові основи використання штучного інтелекту та впровадження системи реєстрації «розумних» машин. Українське законодавство не регламентує правові основи використання творів, створених без участі людини, i автором твору визнає лише фізичну особу. У законодавствах Австралії та США закріплено, що оригінальний авторський твір буде зареєстрований лише за умови, що його створила людина. Таким чином, захист авторського права мають лише твори інтелектуальної праці людини.

Зважаючи на різне відношення до ШІ, сформувались основні підходи до визначення авторства творів, створених штучним інтелектом:

1) автор - розробник штучного інтелекту (комп’ютерної програми чи коду);

2) автор - користувач штучного інтелекту (використання програми фотошоп);

3) автор - безпосередньо штучний інтелект (концепція електронна особа).

Перший та другий підходи є найпоширенішими, але не зовсім відповідають ознаці творів як об'єктів інтелектуальної власності - наявність творчої та інтелектуальної діяльності людини.

Проблема першої концепції полягає у тому, що творча та інтелектуальна діяльність людини - це комп'ютерний код, який є основою штучного інтелекту.

У другій концепції твір, який генерує програма, не містить впливу розробника, оскільки виконує певний алгоритм дій. Користувач штучного інтелекту не є автором об'єкту інтелектуальної власності повною мірою, тому що він лише завантажує певні файли у програму, творчу діяльність при цьому виконує ШІ.

Щодо третьої концепції, то для того щоб штучний інтелект мав змогу користуватись своїми правами та обов'язками, він повинен мати якийсь статус чи правовий режим. Тут виникає питання, чи віднести ШІ до існуючих суб'єктів та наділити його такою ж правоздатністю і дієздатністю, чи прописати всі його права та обов'язки заново.

Правовий статус робота не може бути отриманий з моделі фізичної особи. Оскільки тоді робот буде мати права людини - право на гідність, недоторканність, винагороду, громадянство і т.д. Це суперечить Хартії основних прав ЄС і Конвенції про захист прав людини і основних свобод.

Правовий статус не може бути отриманий і з моделі юридичної особи, оскільки вона передбачає наявність людей, які представляють ії та керують нею.

Штучний інтелект, фізично втілений в об'єкт робототехніки, повинен розглядатися в якості суб'єкта правовідносин, можливо, десь посередині між юридичними і фізичними особами, поєднуючи їх окремі риси з урахуванням відповідної специфіки. Можливо, ШІ буде одночасно розглядатися і як об'єкт, і як суб'єкт права.

У проєкті Резолюції про правовий статус роботів пропонується покласти основну відповідальність на розробника/виробника, а також в деяких випадках розділити відповідальність між виробником і власником. Тобто ми можемо мати нову категорію суб'єктів - електронні особи - це новий правовий статус, який має бути введений у правопорядок, не зашкодивши іншим вже існуючим учасникам правовідносин. Для імплементації цієї категорії законодавці мають відповісти на питання, що таке робот та яке місце він повинен зай- 
мати в цивільних правовідносинах: - це суб'єкт чи об’єкт права; - як він буде нести відповідальність за завдану шкоду; кому будуть належати права на винахід.

Таким чином, головне питання полягає не у визнанні авторства за штучним інтелектом, а у законодавчому визначенні особи, якій будуть належати майнові права на об'єкт, створений програмою. Наразі, можна визнавати автором твору створеного штучним інтелектом розробника самого штучного інтелекту. Теперішня редакція Закону України «Про авторське право та суміжні права» чітко визначає, що автором може бути фізична особа, яка свою працею створила твір. Теоретично можна визначити штучний інтелект винаходом розробника і охороняти права інтелектуальної власності на твори оминаючи ШІ, тобто напряму прив'язувати їх до винахідника. Але до обов'язків, а особливо до покарання за їх невиконання виникають більш серйозні питання. До ШІ такі ж види юридичної відповідальності, як і до громадян, фактично не застосуєш. Санкції потрібно адаптувати до особливостей штучного інтелекту. В силу того, що він є фактично безсмертним, то вирок до довічного ув'язнення буде сумнівним і не вигідним, тому пропонується застосовувати «юридичну смерть». Тобто в разі порушення законодавства визначеної країни пропонується просто стирати програмний код для уникнення подальших дій ШІ.

Варто пам'ятати ч. 2 ст. 50 Кримінального Кодексу України - покарання має на меті не тільки кару, а й виправлення засуджених, а також запобігання вчиненню нових злочинів як засудженими, так і іншими особами. Але до штучного інтелекту це не застосується. Та ж сама психологічна допомога чи усвідомлення своєї поганої поведінки не зовсім уявляється в контексті ШІ.

Висновки. За своєю сутністю штучний інтелект - це галузь комп'ютерних наук, яка намагається відповісти на питання Тюрінга стверджувально. Це і є спробою відтворити або хоча б змоделювати людський розум в машинах. Поки що широкого розповсюдження набули штучні інтелекти простого типу, які не здатні навчатись, запам'ятовувати минуле та прогнозувати майбутнє. Вищим ШІ є самоусвідомлюваний тип, який може створювати об'єкти інтелектуальної власності самостійно, вміє навчатись, осмислювати інформацію та прогнозувати свої подальші кроки. Для такого нового об'єкта права потрібно створити особливий правовий режим, який би захищав права та створював обов'язки для нього.

До тих пір, поки відповідальність, володіння, розпорядження та користування майном ШІ покладається на виробника або користувача об’єкта робототехніки, не викликає ускладнень визначення суб' єкта правових відносин або суб'єкта права. Але у випадку розробки програмного забезпечення з відкритим початковим кодом (коли його розробниками є невизначена кількість осіб), а також самоусвідомленого типу ШІ визначити виробника буде недостатньо, а отже - відповідальну особу також.

${ }^{1}$ Всемирная организация интеллектуальной собственности. Основы интеллектуальной собственности. Киев: Изд. дом «Ин Юре», 1999. 600 с.

2 Пічкурова 3.В. Систематизація теоретичних положень та наукових поглядів на економічний зміст інтелектуальної власності: зб. наук. праць. Наукові записки Національного університету «Острозька академія». 2013. Вип. 24. С. $215-219$ (Серія «Економіка»).

${ }^{3}$ Feigenbaum E.A. Artificial Intelligence: Themes in the Second Decade. IFIP Congress. 1968. V. 2. P. 1008-1024.

4 Reto Hilty, Jörg Hoffmann, Stefan Scheuerer. Intellectual Property Justification for Artificial Intelligence. In Business Law Blog. URL: https://www.law.ox.ac.uk/business-law-blog/blog/2020/06/intellectual-property-justification-artificial-intelligence

\section{Резюме}

Тимошенко $C . A$. Штучний інтелект як суб'єкт права інтелектуальної власності.

У статті розглянуто штучний інтелект (ШІ), як новий і вже існуючий суб'єкт правовідносин. Детально описано його можливість бути повноцінним учасником відносин права інтелектуальної власності. Штучний інтелект дає змогу комп'ютерам навчатися на власному досвіді, адаптуватися до заданим параметрам і виконувати ті завдання, які раніше були під силу тільки людині. У більшості випадків застосування штучного інтелекту, чи то для гри в шахи, чи то як безпілотного автомобіля, вкрай важливою $є$ можливість навчання і обробки природної мови. Важливо вже зараз почати адаптувати законодавство під майбутні реалії. Необхідно визначити коло прав та обов'язків ШІ, вказати його правовий статус. Відповідно, потрібно визначити, хто буде законним носієм всіх прав та обов'зків, які виникнуть у результаті створення певного творчого об'єкта.

Ключові слова: право інтелектуальної власності, право власності, штучний інтелект, суб'єкт, правовий статус, винахідник.

\section{Резюме}

Тимошенко E.A. Искусственный интеллект как субъект права интеллектуальной собственности.

В статье рассмотрены искусственный интеллект (ИИ), как новый и существующий субъект правоотношений. Подробно описано его возможности быть полноценным участником отношений интеллектуальной собственности. Искусственный интеллект позволяет компьютерам учиться на собственном опыте, адаптироваться к заданным параметрам и выполнять те задачи, которые раньше были под силу только человеку. В большинстве случаев применение искусственного интеллекта, то ли для игры в шахматы, то ли как беспилотного автомобиля, крайне важна возможность обучения и обработки естественного языка. Важно уже сейчас начать адаптировать законодательство под будущие реалии. Необходимо определить круг прав и обязанностей ИИ, указать его правовой статус. Соответственно, нужно определить, кто будет законным носителем всех прав и обязанностей, которые возникнут в результате создания определенного творческого объекта.

Ключевые слова: право интеллектуальной собственности, право собственности, искусственный интеллект, субъект, правовой статус, изобретатель. 


\section{Summary}

Yelizaveta Tymoshenko. Artificial intelligence as a subject of property law.

The article considers artificial intelligence (AI) as a new and existing subject of legal relations. It is described in detail about his ability to be a full participant in the relationship of intellectual property rights. Artificial intelligence allows computers to learn from their own experience, adapt to given parameters and perform tasks that previously could only be done by humans. In most cases, the use of artificial intelligence, whether for playing chess or as an unmanned vehicle, is extremely important to be able to learn and process natural language. That is, the development and awareness of AI is needed. Thanks to information technology, computers can be "taught" to perform certain tasks by processing large amounts of data and identifying patterns in them.

Artificial intelligence is not in itself identical to the concept of "process automation", but the development of AI will lead to the fact that more and more tasks will be under the power of a computer program. Therefore, it is important to start adapting the legislation to future realities now. It is necessary to define the range of rights and responsibilities of AI, to indicate its legal status. Accordingly, it is necessary to determine who will be the legal bearer of all rights and responsibilities that will arise as a result of the creation of a particular creative object. In the field of intellectual property law, AI is seen as a new source of creativity, a source capable of producing new results.

The article offers consideration of these issues in the field of intellectual property, as for several years there are examples of works invented by artificial intelligence. For a long time, programs were just a tool to help the author create a work. However, with the development of machine learning and neural networks, artificial intelligence has learned to create a variety of objects: images, videos, music, design. Since the result obtained by artificial intelligence can be potentially protective, the article discusses the question of who should recognize the rights to objects created by AI.

Key words: intellectual property law; property rights; artificial intelligence; subject; legal status; inventor. 